\title{
sciendo
}

\section{European Union vs. Eurasian Union - a brief comparative analysis and perspectives for cooperation}

\author{
Raluca Maria POPESCU \\ Bucharest University of Academic Studies, Bucharest, Romania \\ raluca.popescu22@yahoo.com
}

\begin{abstract}
The Eurasian Economic Union (EEU) is considered to be the first successful regionalization attempt in the post-Soviet area. It is promoted as an economic organization whose aim is to remove trade barriers, promote integration, cooperation and economic growth in a fragmented and underdeveloped region. The promoters of this organization state that it can represent a platform for dialogue and even cooperation with the European Union, as well as with other international actors. The growing influence of the European Union in the post-Soviet space has been a critical factor in Russia's determination to update its policy towards regional integration and from the very beginning, the European model was chosen to create the new Union.

By doing a comparison between the two regional blocs, I will contribute to a growing literature on the relationship between the European Union and the Eurasian Economic Union, by emphasizing the similarities and differences as well as how the emerging regional competition will shape the future of European relations.

In the first part of the article, I will briefly present the evolution of the integration process after the fall of the USSR, followed by a comparative analysis of the two regional integration projects, from a structural, political and economic point of view. I will conclude by analyzing the chances for any kind of breakthrough in political relations and economic cooperation between the two blocs.

The article follows a qualitative and quantitative methodology and examines the possible implications of a competition between the European Union and Eurasian economic Union.
\end{abstract}

Keywords: European Union, Eurasian Economic Union, trade relations, regional integration, economic growth, competition.

\section{Introduction}

Since the fall of the USSR, the Russian Federation has sought new ways to encourage the formation of new regional agreements and organizations in the Eurasian area, targeting the newlyindependent countries of the former Soviet Union that were small and economically weak at the time, in an effort to increase its own influence at a regional level. In other words, it sought to create new connections, new ties, in the place of the old ones forged by the communist regime. This type of external policy reflected both Russia's ability as well as its wish to regain its position as a regional hegemon. Thus, since the 1990s, the development of the regional integration process has become a foreign policy priority for the Russian Federation.

Comparing the two regional blocs from various points of view: economic, financial, geo-politic, structural, has been done by researchers of various academic schools. A common view among many is that the Eurasian Economic Union has been created to put a stop to the growing influence of the European Union (mainly through its Eastern Partnership initiative) in the eastern part of the continent and at the same time as a means to reassert Russia's position in the contested region. 
Five years have passed since agreement for the creation of the Eurasian Economic Union came into force, but there are still serious economic imbalances between the five member states of the Union; also, the purported integration positive results are quite ambiguous. Due to unfavorable external conditions, such as the sanctions imposed on Russia and the COVID 19 pandemic, the positive trade effects of the implementation of the EEU treaty have been at best modest.

The importance of the present study lies in the analysis of the geopolitical situation and possible medium-term changes in the European political scene caused by the emergence of a new regional organization, led de facto by the Russian Federation and whether the Eurasian Economic Union could become an effective tool for recapturing the lost Russian hegemony in the region of Eastern Europe and Central Asia.

\section{Literature review}

Many analysts view the Eurasian Economic Union and its future development opportunities with skepticism, although the organization now has a stronger institutional structure than the previous organizations upon which it was built. Even if the EEU is not a reliable alternative to the European Union, the latter must change its approach to Eastern Europe, thanks to Moscow's foreign policy agenda (Dragneva and Wolczuk, 2012).

Critics view the EEU as an instrument of power for Russia and as the main tool in its plan to regain hegemonic status in the region. In addition, it is seen as a destabilizing initiative aimed at limiting the European Union's influence in the region and limiting EUE members' ties with the West. On paper, it is an economic organization, but at its core is a political one; set up mainly to counter the expansion of the Western European Union and China to the east (Popescu, 2014).

Western analysts generally agree that Moscow's preeminent reason behind the creation of the Union was to devise a regional bloc fully oriented and dependent on the Russian Federation. As many agree, in order to be viewed as a superpower and to be able to compete with the EU on equal footing, Russia needs to lead a regional union (Delcour, 2015).

The Eurasian Economic Union is a new organization, the integration processes are still in progress, thus further enlargement as well as the possibility of disintegration of the whole process cannot yet be ruled out. However, authors such as Hartwell (2016), Kuzmina (2015) and Zagorski (2015) consider the Eurasian Union as the most ambitious and successful model of regional integration in the former Soviet zone. Vinokurov (2017) shares their opinion but states that the Union is not necessarily a success story but it is still a functional customs union. Dragneva and Wolczuk (2017) consider the Eurasian Economic Union a success as member countries have made real progress in the fields of harmonization of legislation and commercial practices in a short period of time. Convergence in domains such as trade policies is crucial for the future development of the Union (Blockmans et al., 2012). On the other hand, Delcour (2017) and Kubicek (2009), consider that this project does not have an economic purpose but only a political one, to consolidate the status of the Russian Federation as a regional power and to prevent the expansion of the European Union and China in areas where the Russian Federation has historically been influential. Several specialists claim that union is weak, as member states have a different level of development, their economies are still in transition and are controlled by the state. They are also heavily dependent on the global market for the demand for natural resources and other primary products. Taking into account all these factors, the EEU is seen by some specialists as a market that is too uncompetitive and too small to become an alternative to the European Union market (Libman, 2014). 


\section{Methodology}

In order to analyze and develop the established research objectives, the article follows a qualitative analysis of relevant literature using as tools: scientific articles, journal publications, reports of the European Commission, reports and legal documents of the European Union and other international organizations. This qualitative research will present an overview of the policies and strategies used by the European Union and the Eurasian Union.

The qualitative analysis will be completed with quantitative data on the economic status of

PICBE |

1296 the two integration projects. The quantitative method will allow us to draw conclusions about the economic attractiveness of both the EU and the EEU for third parties. Statistical data will be extracted from both secondary and primary sources, using databases such as Eurostat, World Data Bank, as well as statistics and reports from EU and EEU institutions. The economic indicators will allow for an overall comparative analysis.

\section{Results and discussions}

Integrationist processes are an indispensable part of the world economy, of contemporary international relations and are promoters of continuous globalization. They became a significant phenomenon on the world stage in the second half of the twentieth century, starting with the creation of the European Coal and Steel Community which evolved over the course of a few decades to become the European Union (EU) in 1992.

The European Union, at the present, has reached the deepest levels of integration when compared to other similar integrationist organizations. It represents a political and economic structure that comprises both the characteristics of an international organization and the particularities that characterize the State (or Superstate). Formally, however, the EU does not clearly represent any of these facets. In regard to some cases, decisions are taken by supranational bodies, basically similar to those of the state (parliament, council of ministers), in other cases, the decision-making process involves negotiations between Member States. In this sense, within the EU, two lines of the administrative-decision-making process coexist, "at a community level" and "at a federal level" (Beniuc et al., 2015).

On the other hand, the Eurasian Economic Union is still a new regional integration project, having entered into force only 5 years ago and unlike the former which developed into the organization we know today organically over a couple of decades, the Eurasian Economic Union has undergone what is considered by many to be a forced and imposed integration. More to the point, structurally, the EEU is a four-tiered organization, where all decisions can be overruled by the Intergovernmental Council (composed of member stated heads of government) and where the organizations have quite limited supranational competencies when compared to those of the EU.

Another aspect that differentiates the two organizations is that the whole process of creating the EEU, from the establishment of the Customs Union in 2010 to the adherence of Armenia and Kyrgyzstan in 2014 has been extremely short, being described by some analysts as "rushing" towards regional regionalization (Roberts, 2017) - in other words, we witnessed an extremely fast and intensive integration process that covered a lot of processes and steps in a short period of time. This reality may lead in the near future to increased economic disparities and disagreements between member states due to inefficient cooperation mechanisms and delayed uniformization of rules and procedures.

The most ambitious aspect of the EEU is the attempt to emulate the European integration project. Sergei Glazyev, one of Putin's main advisers on Eurasian integration, confirmed that the 
Union "follows the general outlines of European integration" and that the program aims to increase economic competitiveness by "giving up some sovereign rights" in order to deepen the integration between member states and harmonize national laws, as he considers these actions to be the key leading to the success of the union. (Glazyev and Tkachuk, 2015). All the presidents of the member states gave speeches outlining the parallels between the Eurasian integration model and the European Union model and suggesting that the European model is indeed the model the EEU is trying to follow (Nazarbayev, 2014).

Some of the reasons for this intensive integration phase that took place between the years 2010-2015, include the effects the global financial crisis of 2008 had on the eastern European states, but also the desire of Member States' leaders to stimulate trade, investment and increase competitiveness in a region of the world that was slow to adapt to the demands of a globalized and interconnected economy. Another important factor noted by some analysts is the recent willingness of member states to delegate a recently acquired sovereignty (just over 30 years ago), which was rigorously guarded in the early post-Soviet years (Glazyev and Tkachuk, 2015 ).

The EEU traces back its origins to January 1995, when Russia, Belarus and Kazakhstan signed their first treaty to form a Customs Union, an organization which was later joined by Kyrgyzstan and Tajikistan (Kirkham, 2016). Economic integration at that specific moment was determined, among other things, by the disastrous impact of capitalist policies and free-market economics on post-Soviet economies. By mid-2000, the project had been joined by the Republic of Kazakhstan, the Kyrgyz Republic and the Republic of Tajikistan, and thus the organization evolved to the next step, transforming into the Eurasian Economic Community (EurAsEC). However, before the 2000s, little progress was made, despite several initiatives including the Commonwealth of Independent States (1991), a Customs Union, the Eurasian Economic Community (2000); all of which ultimately failed.

The next step envisaged by the governments was to create a Common Economic Space modeled after the European Union, which was supposed to include Russia, Belarus, Kazakhstan and Ukraine. The initiative, however, was short-lived; when the news broke in Ukraine in 2004, it led to large scale protests, a true social movement that came to be known as the "orange revolution". As a result, in 2007 the Agreement for the formation of a Customs Union was concluded only by Russia, Belarus and Kazakhstan. The Agreement established the Customs Union Commission in order to monitor and foster the processes of integration. Furthermore, in January 2010 a common customs tariff was implemented at the external borders of the Customs Union, taking the regional integration process a step further (Dragneva and Wolczuk, 2012).

The first concrete steps towards regionalization began in 2007 when Russia, Kazakhstan and Belarus declared their intention to create a customs union within the Eurasian Economic Community - the Eurasian Customs Union. Unlike many previous attempts at integration into the post-Soviet space, this initiative has been a success, with member states succeeding in taking important steps towards economic integration, January 2015 was another important step towards an increased regionalization of the member countries of the Customs Union, with the creation of the Eurasian Economic Union and the accession of two new members Kyrgyzstan and Armenia.

A more controversial aspect of the EEU is the geopolitical component and, in particular, the perception that many Western states have regarding this organization, namely that Eurasian integration is a manifestation of Russia's hegemonic ambitions in the region. A wide range of studies have focused on this geopolitical component, in an attempt to explain the existence of the UEE, especially when looking at the speed with which this Union was established, as well as the geopolitical context that precipitated the process (Adomeit, 2012; Dragneva, 2017). When 
analyzed from this perspective, the union is only an attempt made by Putin to directly counter the new series of Association Agreements offered by the European Union to certain eastern European states (Adomeit, 2012) or a reaction to changes in the international hierarchy, at a time when Western power is called into question (Krickovic, 2014).

\section{Eurasian Economic Union - a replica of European Union architecture?}

With the creation of the Eurasian Union, member countries have set themselves the goal of achieving a high level of integration. For this purpose, they have assumed obligations to guarantee the free movement of: goods, services, capital, labor, as well as to create common policies in the fields of energy, industry, agriculture and transport.

When we compare the EU and EEU institutions and their respective roles, we can clearly see that the institutional structure of the Eurasian Economic Union is in fact a copy of the European one. For example, since 2012, a common supranational institution has been established following the European model, acting as the Union's regulatory body - the Eurasian Economic Commission (EEC), institution was taken over by the UEE. The Eurasian Economic Commission is a supranational body that provides all the conditions for the future development of the Union and draws up proposals in the economic field. The Commission's headquarters are in Moscow.

The main executive body of the EEU is the Council, which consists of 10 ministers, each Member State being represented by 2 ministers. Such a representation scheme diminishes Russia's role as a leader of the regional organization, although Russia contributes $87 \%$ of the Union's total GDP, with $20 \%$ of the total voting power.

The Commission Council is similar to the EU Council, in that it is an intergovernmental body that can revoke or amend Council decisions. However, there are differences, for example: in the EEU, the Council is part of the Commission, not a separate institution; Member State governments are represented by Deputy Prime Ministers, rather than Ministers; also decisions are always taken by consensus, without provisions on majority voting (Kirkham, 2016).

The Court of the Eurasian Economic Union, based in Minsk, is the permanent judicial body of this organization. It is a specialized body empowered to settle disputes relating to the implementation of international treaties signed by the Union and to ensure that the decisions of the union's governing bodies are implemented correctly and on time. Its decisions, such as decisions on the Common Customs Tariff, have direct effect in the Member States of the Union and are binding. The Court examines mainly applications for the establishment of specific Union import quotas. Unlike the EU, which has a complex and efficient legislative system, the legal framework and institutions empowered to manage the activities of the Eurasian Union are still in development and the jurisdiction of the EEU Court is quite limited. Firstly, the Court cannot compel a member state to apply the union law. Secondly, national courts cannot submit to the Court an appeal for a preliminary ruling, that is to say, they cannot ask the court to interpret union law. Without such a procedure, national courts may come to interpret the rules and regulations differently.

The Eurasian Supreme Council is similar to the European Council in that it decides on the overall direction of the integration process during high-level meetings, which take place at least once a year, in addition to selecting the members of the Commission's Management Board.

A critical difference between the two organizations is the lack of a strong legislative power in the framework of the EEU, a fact which stands in stark contrast to the EU functional structure, thus the EU has a Parliament, a supranational body directly elected by the citizens of member states. The Eurasian Economic Union has no such structure so far; and if one were to be created, it would be most likely modeled on former structures from CIS, CSTO and EurAsEC, former 
organizations that possessed weak inter-parliamentary bodies consisting of deputies from national legislatures, that were designated by the governments (Popescu, 2014).

European Union supranational institutions are better suited to manage the power disparities between member states, and because they are given powers to make binding decisions, potential hegemons such as Germany or France are constrained by complex rules and mechanisms that redistribute power and influence, as well as by supranational bodies such as the European Commission and the European Court of Justice. The EU has developed, over time, efficient legislative instruments to support a single market. Another key difference between the two organizations is that the governance of the Eurasian Economic Union is characterized by a pyramidal structure, which differs from the institutional structure of the EU (Kirkham, 2016).

\section{European Union vs. the Eurasian Economic Union - brief economic comparison}

The European Union includes countries of different size, economic power and geopolitical weight, while the Eurasian integration process is dominated by Russia, which is the main economic and political player. The problem and at the same time, one of the distinguishing features of the Eurasian Union is that it is composed of countries that have been part of the same structure. Thus, the integration process is mainly focused on restoring the old ties between members. Due to this situation, there are problems related to the reconciliation of strategic objectives, in the sense that it is difficult for the Russian Federation to relinquish many of its great power prerogatives and to become a partner with equal rights.

The development process of both organizations is obviously different, differing in substance, as well as with regards to the initial purpose of their creation. For example, the creation of the European Union was created in an effort to regulate and balance the economic development of member states, especially that of Germany and France, by controlling the production of coal and steel of these two countries. The control was to be carried out, in Shuman's opinion, by a "Common Higher Body within the organization which would be open to the participation of other European countries." 1 The Union of Coal and Steel Production was immediately to provide the common basis for economic development as a first step towards the European Federation". In other words, the creation of this organization was aimed at preventing the emergence of new conflicts and at the same time ensuring that European security could be achieved, by putting the economic, military and technological potential of the great European powers, under institutionalized control (Beniuc et al., 2015).

On the other hand, the basic purpose for the creation of the Eurasian Economic Union was initially a strictly economic one. Socio-economic degradation of post-Soviet countries after the disintegration of the USSR, the disappearance of traditional economic relations, the disappearance of the central economic administration that existed in the Soviet Union, loss of qualified workforce in the administrative and economical fields, together with the inability national elites to maintain and develop the economic level reached by 1990 imposed the immediate need for the CIS states to sign various interstate agreements, especially agreements of an economic nature.

Another aspect worth mentioning is that the EEU member countries place great emphasis on national sovereignty, and because of this they are not prepared to relinquish any of the prerogatives of state power, they are reluctant to delegate power, moreover there is no Parliament

\footnotetext{
${ }^{1}$ Schumann declaration. Accessed at: https://europa.eu/european-union/about-eu/symbols/europe-day/schumandeclaration_ro
} 
of Eurasian Union, which does not allow a direct representation of citizens. Another key difference is the lack of a common economic policy within the Eurasian Economic Union.

The Eurasian Economic Union covers an area of 20.2 million $\mathrm{km}^{2}$ (15\% of the globe, ranked 8th in the world), has a population of about 18 million inhabitants and an estimated GDP of \$ 4.778 billion. The average GDP per capita was 8,500\$ in 2020 (Eurostat, 2020).

On the other hand, the European Union, covers an area of 4,476 million $\mathrm{km}^{2}$, has a population of 447.7 million inhabitants and a GDP of \$ 19.397 billion. The average GDP per capita was $43,615 \$$ in 2020 . Analyzing the data, we can see that the EEU economy is four times smaller and has a GDP / capita 2.35 times lower than that of the European Union (Eurostat, 2020).

The EU-27 is a major player on the world market, accounting for about $15 \%$ of the world trade in goods (counting both imports and exports), ranking third in the world in the international trade hierarchy, after China and the United States. The value of international trade in goods significantly exceeds that of services (about three times larger). Moreover, in 2019, the total level of trade in goods for the EU-27 was EUR 4071 billion (excluding intra-EU trade). The EU-27 is the second largest net exporter of goods in the world, after China, amounting to $15.4 \%$ of the world total (Eurostat, 2020).

On the other hand, the EEU accounts for only $1.8 \%$ of world trade. It is important to mention that it has a significant share in world energy trade, respectively $6.6 \%$ share of the world market. In other words, the organization is not a major player in international trade; but it plays an important role in the energy market.

Despite the deteriorating relations between the European Union and the Russian Federation, in 2019, the organization remains an important trading partner for the EU, ranking 4th after the USA, China and the United Kingdom. More to the point, Russia is EU's fifth largest trading partner (going even as high as 3rd place in 2013) with $5.7 \%$ of total external trade (Eurostat, 2020). In addition to this, in 2019, the ratio of exports to imports for the EU (trade balance) was particularly high in favor of exports to the Russian Federation (Eurostat, 2020).

EEU exports to the EU are made up in proportion of $80 \%$ of raw materials, especially oil and natural gas. In addition, the EU is the main market for EEU member states with 50.5\% of exports in 2019 (Eurasian Economic Commission Report, 2020). The Russian Federation and Kazakhstan are the strongest economies in the EEU but both are heavily dependent on natural resource production, which accounts for $11 \%$ of GDP in Russia and $15.5 \%$ in Kazakhstan, accounting for $66 \%$ and $63 \%$ of exports, respectively (Eurostat, 2020). The economy of Belarus is also dependent on the oil and gas sector; for example, oil processing accounts for more than half of Belarus' domestic production and 33\% of the country's exports (Eurostat, 2020). The value of this type of trade is volatile and fluctuates along with global demand. Oil prices, production volumes are also variable, which makes the economies of EEU member states extremely sensitive to external shocks. This cannot be said for the majority of the economies of EU member states; their economies are much more differentiated and service based than those of the EEU.

The Russian Federation dominates the EEU politically and economically; for example, in 2019, trade with Russia accounted for $96.9 \%$ of total trade in the Eurasian Union; trade between the four smaller countries accounted for the remaining 3.1\%. Of the total trade volume recorded by the Russian Federation, only $8 \%$ is made with the other EEU member states. It is the lowest percentage in the union and even fell slightly, from around $10 \%$ in 2000 . In other words, the Russian Federation is the least dependent on the bloc for foreign trade. 
It is important to note that for the Eurasian Economic Union, trade with third countries is much more important than internal trade. In the last year the value of intra-EEU trade increased by $2.3 \%$ compared to 2018 reaching \$ 61.6 billion (Statistica, 2020).

The trade balance between the two organizations has been severely affected by the sanctions imposed on Russia, and since the formation of the EEU the figures have been steadily declining (Statistica, 2020). In 2017, as oil prices stabilized, trade (intra- and extra-EU) began to recover, albeit far from pre-2014 figures. However, EU-EEU trade suffered heavy losses.

Intra-EEU trade, although relatively low for a regional organization that has removed trade barriers, increased from $12.3 \%$ of total trade in 2014 to $14.6 \%$ in 2017 . In 2018, rising commodity prices led to a reversal of this trend, and the share fell to 13.5\%. In 2019, intra-EEU trade increased by $2.3 \%$ compared to the previous year, to $\$ 61.6$ billion (Eurasian Economic Commission Report, 2020). By comparison, the value of intra-community trade for the EU amounts to $\$ 256.3$ billion (Eurostat, 2020). Given the commercial prowess of the Russian Federation, the EEU offers few economic advantages, while the costs of integration are not negligible, as they are mostly borne by the former. However, the country bears these costs for the geopolitical benefits that this regional bloc brings.

Taking into account all of the above, the European Union dominates from an economic point of view and if we take into account all these indicators it is clearly the more advantageous option for third countries.

\section{State of affairs. Prospects for cooperation}

When analyzing the relations between the two regional organizations, particular attention should be relegated to understanding the relationship between the EU and the Russian Federation, a relationship that dominates the diplomatic discourses between the two blocs.

EU-Russian Federation relations remained fairly stable from 1990 until the 2000s, when the European Union began its "eastward expansion" by creating platforms for cooperation with former communist states. Such platforms were the European Neighborhood Policy followed by the Eastern Partnership. These two initiatives sparked rivalries between these two integration blocs. The updating of the Partnership and Cooperation Agreements (PCA's) through the introduction of the Association Agreements has led to increased competition between the EU and Russia. In 2009, the EU offered Association Agreements to five former Soviet states: Armenia, Georgia, Moldova, Ukraine and Azerbaijan. These agreements have been much more comprehensive compared to the former Eastern Partnership PCA's. The EU promised the countries signing these agreements economic growth and development, by encouraging the adoption of high standards of governance, democracy and policies for market liberalization. By introducing these agreements, the EU has developed a more attractive policy platform for its eastern neighbors. Thus, for the first time, the EU has become a real challenge for Russia and for the latter's influence in the region. Although the EU does not offer membership, the influence the organization can achieve through these cooperation mechanisms is significant. In June 2014, the Association Agreements were already signed by Georgia, Moldova and Ukraine (Delcour, 2014).

Membership in the Eastern Partnership and participation in the Deep and Comprehensive Free Trade Agreement (DCFTA) does not prevent the signing countries from maintaining relations with the Russian Federation or the Eurasian Economic Union and does not in any way affect pre-existing trade relations. Under existing regulations, the DCFTA allows acceding countries to take part in any kind of free trade agreement. 
On the other hand, membership of the Eurasian Economic Union requires a greater commitment, requiring states to relinquish sovereignty over their foreign trade policy. In other words, member states waive the right to negotiate bilateral or multilateral free trade agreements with third parties. In addition to this restriction, they are required to follow a set of mandatory rules on the elimination of non-tariff barriers to trade and respect the common customs tariff. It is important to note that as the EEU is a customs union, members cannot sign unilateral free trade agreements with other countries. By comparison, the EU used Free Trade Agreements (DCFTAs) as the main tool for promoting its relations with countries from the former Soviet bloc. Russia's decision to penalize Ukraine for signing the agreement is a harsh diplomatic signal to both the EU and neighboring countries that it will not accept Western intrusion into what it considers its historical space of influence.

The EEU is still in its infancy and has only 5 members, but the Russian Federation has at least managed to discourage some Eastern European countries from developing closer economic relations with the European Union; for example: Armenia, Georgia, Ukraine and Moldova. However, to date, the EEU has not provided a viable long-term alternative to the EU single market integration and remains by far the largest trading partner for the 4 countries concerned, while Russia's relative share has fallen. over the years.

The Crimean crisis was a turning point that severely affected the already deteriorating relations between the Russian Federation and the EU. Since the conflict began in late 2013, the EU-Russia Strategic Partnership (signed in 2003) has been suspended, with the two blocs currently in the deepest crisis since the end of the Cold War.

Thus, the relations between the EU and the Russian Federation deteriorated after the annexation of Crimea, and at the moment we cannot say that there is a diplomatic dialogue between the two. The EU condemned the incident, imposing harsh sanctions in an attempt to isolate Russia economically and politically. It is clear that with the imposition of these sanctions, EEU's economy has declined in almost all sectors, and EU-EEU trade relations have also been severely affected (Popescu, 2014).

The EEU is a key part of the Russian Federation's strategy to achieve its global aspirations, and the organization's foreign relations reflect Moscow's strategic priorities. Taking this into account it is clear that geopolitical considerations dominate economic ones, affecting both the type of trade commitments made and the potential economic benefits to be made.

\section{Conclusion}

All the economies in the Eurasian Economic Union have already experienced the negative consequences of the European Union sanctions against Russia, along with the negative impact of declining oil prices, import tariffs, weakening demand and depreciation of the Russian ruble. The situation hasn't improved much since 2015 (when the countries were hit hardest) and with the current global situations and the Covid 19 pandemic; economic growth within the EEU or a future expansion seems improbable. Despite its rather strong start and fast integration, the EAEU is criticized by many for being a very costly endeavor and in the end a rather weak organization by conceptual dimension, making many analysts and politicians doubt its viability in the long run. Russia seems at least for the time being ill equipped to push for an enlargement of the union.

Nevertheless, with two competing integration initiatives, the countries located between the two blocks are put in the difficult position of having to choose between the two, as it became clear in recent years that Russia would not condone dual allegiances. As a whole, the European Union 
is facing up to a new set of internal and external conditions which affects its approach to the eastern European countries.

Taking into consideration all of the above, a ,cold partnership" is the most plausible scenario for the future of EU-EEU relations, in other words a pragmatic partnership that preserves peace and stability in Europe. Close cooperation the two between regional organizations (in the economic sphere, in the field of security, in the fight against organized crime, trafficking in human beings and goods) does not seem possible in the near future.

Managing a difficult relationship and preventing it from deteriorating seems to be the best policy today. A reset of EU-Russia relations does not seem possible at the moment and there are no "new political currents" in Europe or Russia that can change the current climate.

\section{References}

Adomeit, H. (2012). Putin's Eurasian Union: Russia's Integration Project and Policies on PostSoviet Space, Neighborhood Policy Paper, CIES, July 2012.

Aleksashenko, S. (2012). Russia's economic agenda to 2020 in International Affairs, 88, 31-48.

Beniuc, V., Rosca, L., Afanas, N. (2015). Uniunea Europeana - Uniunea Euroasiatica: Studiu Comparat. Institutul de Relatii Internationale din Moldova.

Brusis, M. (2014). A Eurasian European Union? Relaunching Post-Soviet Economic Integration, Mimeo.

Cameron, D., Orenstein, M.A. (2012). Post-Soviet Authoritarianism: The Influence of Russia in Its Near Abroad, in Post-Soviet Affairs, 28(1), 1-44.

Delcour, L. (2011). Shaping the post-Soviet Space? EU Policies and Approaches to RegionBuilding, Farnham, Ashgate.

Delcour, L. (2015). Between the Eastern Partnership and Eurasian Integration: Explaining PostSoviet Countries' Engagement in (Competing) Region-Building Projects in Problems of Post-Communism 62(6), 316-327.

Delcour, L., \& Kostanyan, H. (2014). Towards a Fragmented Neighbourhood: Policies of the EU and Russia and their Consequences for the Area that Lies in between, Brussels: CEPS.

Dragneva, R. (2013). The Legal and Institutional Dimensions of the Eurasian Customs Union, in Eurasian Economic Integration. Law, Policy and Politics, Cheltenham, Edward Elgar, 34-61.

Dragneva, R., Wolczuk, K. (2012). Russia, the Eurasian Customs Union and the EU: Cooperation, Stagnation or Rivalry in Chatham House Briefing Paper, REP BP 2012/01.

Dragneva, R., Wolczuk, K. (2017). The Eurasian Economic Union Deals, Rules and the Exercise of Power, in Chatham House Briefing Paper.

Dragneva, R., \& Wolczuk, K. (2017). The Eurasian Economic Union: Deals, Rules and the Exercise of Power, Chatham House Research Paper, May.

Dragneva-Lewers, R., Wolczuk, K. (2015). Trade and geopolitics: should the EU engage with the Eurasian Economic Union? European Policy Centre Policy brief http://www.epc.eu/ documents/uploads/pub_5462_trade_and_geopolitics.pdf.

Dzarasov, R. (2016). The Global Crisis and Its Impact on the Eurasian Economic Union in European Politics and Society, 17(S1), 23-34.

Eurasian Development Bank (2020). Eurasian Economic Integration 2019, accessed at: EDB_ Centre_Report_52_Eurasian_Economic_Integration_2019_eng.pdf. 
European Parliament Brief (2017). Eurasian Economic Union The rocky road to integration, accessed at: https://www.europarl.europa.eu/RegData/etudes/BRIE/2017/599432/EPRS_ BRI(2017)599432_EN.pdf.

Glazyev, S., and Tkachuk, S. (2015). Eurasian Economic Union: achievements and prospects in Dutkiewicz, P. and Sakwa, R. (eds) Eurasian integration-the view from within, Oxford: Routledge, 61-83.

Hancock, K. (2009). Regional Integration: Choosing Plutocracy, Basingstoke: Palgrave MacMillan.

Hartwell, Ch. A. (2016). Improving Competitiveness in the Member States of the Eurasian Economic Union: A Blueprint for the Next Decade in Post-Communist Economies, 28(1), 49-71.

Kirkham, K. (2016). The formation of the Eurasian Economic Union: How successful is the Russian regional hegemony?, Journal of Eurasian Studies, 7(2), July, 111-128.

Krickovic, A. (2014). Imperial nostalgia or prudent geopolitics? Russia's efforts to reintegrate the post-Soviet space in geopolitical perspective, Post-Soviet Affairs, 30(6), 503-528.

Libman, A., Vinokurov, E. (2017). Autocracies and regional integration: the Eurasian case in Journal Post communist economies, 30(3), 334-364.

Libman, A., and Obydenkova, A. (2018). Regional international organizations as a strategy of autocracy: the Eurasian Economic Union and Russian foreign policy in International Affairs, 94(5), 1037-1058.

Libman, A. (2015). Ukrainian Crisis, Economic Crisis in Russia and the Eurasian Economic Union. in Munich Personal RePEc Archive Paper No. 63861.

Libman, A., Vinokurov, E. (2014). Do economic crises impede or advance regional economic integration in the post-Soviet space? in Post Communist Economies, 26(3), 341-358.

Kuzmina, E. (2015). The Eurasian Economic Union. Analyses and Perspectives from Belarus, Kazakhstan,and Russia in Friedrich Ebert Stiftung, 8-11.

Nazarbaev, N. (2012). President's Speech: New Kazakhstan Patriotism, available at http://kazakhstan2050.com/patriotism/presidents-speech.

Nitoiu, C. (2017). Still Entrenched in the Conflict/Cooperation Dichotomy? EU-Russia Relations and the Ukraine Crisis, European Politics and Society, 18(2), 148-165, doi:10.1080/ 23745118.2016.1197875.

Popescu, N. (2014). Eurasian Union: the real, the imaginary and the likely, ISS Chaillot papers no. 132.

Trenin, D. (2009). Russia's Spheres of Interest, not Influence, in The Washington Quarterly, 32(4), 3-22.

Vinokurov, E. (2017). Eurasian Economic Union: Current state and preliminary results in Russian Journal of Economics, 3(1), 54-70.

Wiener, A., and Diez, T. (2005). The European Integration Theory, Oxford University Press.

Wolczuk, K. (2009). 'Implementation without Coordination: The Impact of EU Conditionality on Ukraine under the European Neighbourhood Policy', Europe-Asia Studies, 61(2), 187-211.

Zagorski, A. (2015). The Eurasian Economic Union. Analyses and Perspectives from Belarus, Kazakhstan, and Russia in Friedrich Ebert Stiftung, 4-8. 